\title{
Między akademią a życiem: wiedza naukowa i potoczna w perspektywie doświadczenia osobistego i zawodowego etnografa
}

Wiedza akademicka, którą posiadamy i wciąż poszerzamy, uprawiając antropologiczną profesję, jest podstawowym narzędziem operacyjnym etnologa.

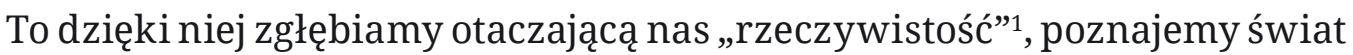
przedmiotów i ludzkich spraw — badamy kulturę. Wykorzystując uczoną nomenklaturę, stosując język naukowego opisu, analizujemy, diagnozujemy i wychwytujemy „konkrety” z plątaniny zjawisk, faktów i znaczeń. Obiektywni lub zakotwiczeni we własnym „ja” przyglądamy się innym i samym sobie, rozpoznajemy „swoich” i „obcych”. Ufni w wyniesioną z uczelni wiedzę wkraczamy na terytoria wydeptane przez poprzedników lub na lądy mniej znane, licząc na odkrycie tego co do odkrycia pozostało.

Postmodernistyczna antropologia rewidując kanony pozytywistycznej etnografii, już od dłuższego czasu zwraca uwagę na badającego, spogląda mu głęboko w oczy i zadaje trudne pytania [Robotycki 1992: 104-109]. Mając świadomość ich powtarzalności (natarczywości?) zastanówmy się jednak, co rządzi naszymi poczynaniami w terenie, w gabinecie, w magazynie i podczas realizacji muzealnych ekspozycji? Czy kierujemy się tu jedynie sztuką akademicką, czy sięgamy także do wiedzy potocznej spoza uczonego kanonu? Zakładając, że tak właśnie niekiedy czynimy, spytajmy

\footnotetext{
${ }^{1}$ Zgodnie z tendencjami postmodernistycznej antropologii, podważającej znaczenie niemal bezdyskusyjnych w epoce modernizmu kategorii (np. „rzeczywistość”, „prawda”, „obiektywizm”), zapisuję je w cudzysłowie.
} 
o jaką przestrzeń wiedzy tu chodzi, gdzie ona była nam zaszczepiona, w jakich pokładach naszego „ja” znalazła schronienie? Gdzie krzyżują się bądź rozmijają ścieżki osobistego (potocznego, „ludowego”) doświadczenia i poznania z drogami wiedzy i poznania akademickiego? W jakim zakresie czerpiemy z tych dwóch zasobów, kiedy w naszej etnologicznej praxis dochodzi do głosu jedno, a kiedy drugie? Mając w pamięci głos Czesława Robotyckiego przestrzegającego nas przed powielaniem starych teorii, referowaniem wielokrotnie wybrzmiałych myśli i popadaniem w banał [Robotycki 1995: 84], spróbujmy jednak znaleźć odpowiedź, choćby tylko na niektóre z postawionych tu pytań.

Wywołane przeze mnie kwestie z pewnością zasługują na głębszą analizę, ale tym razem, choćby ze względu na ograniczoną objętość artyku$\mathrm{lu}$, wiele $\mathrm{z}$ nich pozostawiam $\mathrm{w}$ formie przyczynkarskiej. Odnosząc się do własnych wspomnień i obserwacji sprzed akademickich lat, pragnę podeprzeć naczelną tezę mojego artykułu, że granica między wiedzą naukową a potoczną jest trudna do wytyczenia, a zakresy penetrowanych przez nie tematów i doświadczeń w wielu miejscach pokrywają się. Ten sposób analizy uwzględniający osobiste odniesienie autora nawiązuje do nurtu autoetnografii, który koncentruje się na ewokatywnym programie pielęgnowania żywego doświadczenia oraz na specjalnej roli badacza w procesie poznawczym [Kacperczyk 2014: 34-36]. Osobiste eksperiencje, pamięć, emocje, introspekcja autorska, to również przestrzeń badawcza mikrohistorii utożsamiana z antropologią personalną, zwracającą uwagę na zanurzonego w codziennej rzeczywistości człowieka (autora, badacza), czerpiącego z niej tzw. wiedzę życiową [Domańska 1996: 113-115; Kaniowska 1999: 67-70, 144-145].

Konsekwencją przyjętej tu perspektywy jest styl narracji prowadzonej w duchu postmodernistycznej opowieści, gdzie formuła naukowa przeplata się z literacką, a więc bardziej osobistą (potoczną), waloryzującą swobodną grę skojarzeń, fragmentaryczność wspomnień i sensytywizm doznań [Kaniowska 1999: 122-123, 143-144, 156, 162-166]. Warto przy okazji dodać, że postawa mieszania gatunków i strategii fabularnych, obecna w pisarstwie antropologicznym już od dawna, została uznana za pomocną czy wręcz konieczną w wyjaśnianiu złożonej problematyki jaką podejmuje antropolog [Kaniowska 1999: 130].

Rozważania skoncentrowane na dychotomii nauka/naukowość versus doświadczenie/potoczność nawiązują też do krytycznego nurtu badawczego 
zwanego antropologią antropologii [Kaniowska 1999: 139]. Stąd na końcu mego artykułu refleksję swą prowadzę również i w tym kierunku.

Źródła wiedzy i procesy poznawcze to tematy, które zgłębiali już filozofowie starożytności, a po nich kolejne pokolenia epistemologów: Kartezjusz, Leibnitz, Kant, Husserl, Ingarden, Foucault, Hacking. Problematyka z zakresu teorii poznania zajmuje dziś także antropologów kultury. Wystarczy tu przywołać, jakże często obecne we współczesnej literaturze antropologicznej, rozważania Clifforda Geertza. Wprowadził on swego czasu naszą dyscyplinę na nieeksploatowane wcześniej zbyt często pole badawcze, jakim jest wiedza naukowa, a szczególnie jej miejsce i rola w kulturze, rozpatrywana w opozycji do wiedzy potocznej. Podkreślmy, że Geertz tę drugą zaliczył do osobnej sfery rzeczywistości złożonej z interpretacji danych wynikających z doświadczenia. Nie są to treści przyjmowane spontanicznie ani czysty odruch czy „bez-myślenie”, ale ich strukturze brakuje, charakterystycznego dla sfery nauki, porządku (systematyki) [Geertz 2005: 81-85].

Interpretację kultury Gertza, od dawna zaaplikowaną w szeroko pojętym plemieniu antropologów znad Wisły [Buchowski 1995: 43-55], wykorzystuje się często i z niemałym powodzeniem² ${ }^{2}$ Dariusz Czaja, konfrontujący potoczny styl myślenia ze scjentystycznym postrzeganiem świata, wiedzę potoczną w wykładni amerykańskiego antropologa rozumie jako odpowiedź na życiowe potrzeby, zarówno o charakterze podstawowym co bardziej intelektualnym i uznaje za sferę myślowego oswajania rzeczywistości. Podobieństwa kategorii myślenia potocznego zestawia z wykładnią mitu i mitologii Rolanda Barthesa. Twierdzi, że mit „okazuje się [...] innym imieniem potoczności” [Czaja 2005: 171-172].

Koresponduje to z wcześniejszymi wywodami Teresy Hołówki. Świadomość potoczną definiuje ona jako „zdolność ludzkiego umysłu [...] do rozpoznania i formowania pewnych elementarnych prawd. O jej funkcjonowaniu świadczy fakt, że istnieją przeświadczenia, których nie trzeba uzasadniać, ponieważ są "powszechnie uznane» i «oczywiste dla wszystkich»" [Hołówka 1986: 15]. Myślenie potoczne to myślenie zdroworozsądkowe wynikające $\mathrm{z}$ „potrzeby porządkowania świata w warunkach, gdy trzeba to robić, a odwołanie do nauki jest zbyt trudne” [Czerwiński 1986: 6].

\footnotetext{
${ }^{2}$ Jednym z ostatnich przykładów zastosowania jej w badaniach nad polską historiografią może być praca Wojciecha Piaska [Piasek 2017].
} 
Kategoria potoczności może też się kojarzyć z kulturą popularną, kolejnym aspektem pozaakademickiej rzeczywistości, która najbliższa jest „[...] naszym najbardziej prozaicznym zajęciom” [Krajewski 2005: 31]. Rozumieniu kultury popularnej towarzyszą z kolei relacje z kulturą ludową, czy lepiej z kulturą typu ludowego, bo ta pierwsza stała się przecież już historią [Burszta 1985: 331-332; Robotycki 1992: 13, 17, 25; Barański 2010: 155]. W tym kontekście nie należy zapominać o antropologii codzienności, wychwytującej wszelkie potoczne, nieracjonalne i mityczne zachowania, jakie obserwujemy w naszym powszednim życiu [Sulima 2000].

Warto jeszcze wspomnieć o koncepcji Anny Pałubickiej rozpatrującej dychotomię myślenia spontaniczno-praktycznego (poręcznościowego) i metafizyczno-teoretycznego (pojęciowego). Myślenie praktyczne uznaje ona za pierwotne, upatrując jego genezy w żywiołowych interakcjach społecznych. Nie jest to myślenie abstrakcyjne, a bardziej „narzędziowe”, skierowane na pożytek „radzącego sobie ze światem” człowieka. Łączy się z uprzedmiotowionym wyobrażeniem świata, charakterystycznym głównie dla kultur niepiśmiennych, ale wciąż obecnym w naszej kulturze. Owo wyobrażenie, myślenie i działanie (praktyczne/potoczne) to funkcje wyuczone i przekazywane w procesie pierwotnej socjalizacji [Pałubicka 2006: 12, 46-47, 49].

Podążając za wykładnią Geertza wiedzę potoczną uznać więc można za sprawność szczególnego rodzaju, wcale nie gorszą ani bardziej prymitywną od wiedzy naukowej, choć z nią nieporównywalną [Czaja 2005: 172]. To sposób reagowania na rzeczywistość adekwatny do życiowych potrzeb oparty na naturalności, oczywistości i praktyczności (użyteczności), a jednocześnie na niemetodyczności oraz „nieprzeźroczystości” [Geertz 2005: 91-98].

Zakładając, że człowiek współczesny „[...] zdolny jest do uczestnictwa w kulturze nawykowo albo/i teoretycznie” [Piasek 2011: 61], że w jego myśleniu i działaniu funkcjonują te dwie, równoległe strategie pojmowania i zawłaszczania świata, trudno twierdzić, że ktokolwiek z takiego schematu może być wyłączony. Dotyczy to również „zainfekowanego” akademicką teorią etnologa, wkraczającego w progi uczelni z bagażem owej bezrefleksyjnej wiedzy i osobistych doświadczeń „oddolnych”, które potem, jako wykształcony antropolog, obserwuje (raczej postrzega niż widzi) u badanych [Geertz 2005: 66], a następnie przekłada na język akademickiego dyskursu [Brocki 2012: 47-48]. 
Skoro dotknęliśmy tego ważnego momentu przejścia związanego z nabyciem praw absolwenta do zawodowej aktywności, warto przywołać znamienny dla naszej dyscypliny okres paradygmatycznego przełomu, jaki nastąpił w Polsce pod koniec ubiegłego stulecia [Posern-Zieliński 1995: 22-27]. Interesująca i kłopotliwa zarazem wydaje się sytuacja studenta wykształconego w duchu schyłkowej, ale niemal obowiązującej do lat 80., pozytywistycznej etnografii, którego praca zaczęła się już w innej rzeczywistości. Przyjęcie nowej, określonej w perspektywie antropologii postmodernistycznej formuły metodologicznej wymagało przecież przyswojenia, jakże różnych od obowiązujących wcześniej dyspozycji [Brzeziński 2013: 177].

O ile etnologia akademicka dość szybko wpasowała się w ramy ponowoczesnego paradygmatu, za którego atrybut uznać można m.in. różnej maści relatywizm (nie wszędzie dobrze przyjęty [Bronk 1996: 89; Gellner 1997: 37, 73-74, 124]) $)^{3}$, to muzealnictwo potrzebowało dłuższego czasu na taką transformację. Zakorzenionemu w świecie przedmiotów muzealnikowi pozytywistyczny materializm nie doskwierał zresztą tak bardzo, bo w pracy z obiektami nie sposób mówić o jego absolutnym porzuceniu. Nieobecne dotychczas tematy badawcze, inne perspektywy i nowatorskie ujęcia wkroczyły także do muzeum, choć tempo i zasięg tej ofensywy nie dorównywały akademickiej wrażliwości

Zwróćmy jednak uwagę na współczesnego etnologa, nie tylko jako członka subkultury naukowej, ale jako zanurzonego w życiu społeczeństwa i w kulturze globalnej obywatela. To szerokie, pozaakademickie otoczenie charakteryzuje się przerostem różnorako uporządkowanych informacji, utrudniającym czy wręcz uniemożliwiającym ich przyswojenie. Niespotykana jak dotąd nadpodaż modeli, prądów, opcji, paradygmatów i mód, zabarwiona ideowym liberalizmem i relatywizmem nie daje poczucia oświecenia, a skutkuje poznawczą dezorientacją [Jastrzębski 2017: 11-13]. Trudność odnalezienia się w lawinie znaczeń i faktów paradoksalnie redukuje nas niemal do poziomu człowieka niepiśmiennego. Patrzymy na świat i uzmysławiamy sobie, że w istocie nic pewnego nie możemy o nim powiedzieć, a w najlepszym razie filozoficznie konstatujemy: „wiem, że nic nie wiem”. Tego rodzaju intelektualny dyskomfort będący skutkiem oddziaływania „postfilozoficznego” libertynizmu [Kubina 1998: 19-20], który dotknął także naszą dyscyplinę, często rodzi potrzebę poszukiwania

\footnotetext{
${ }^{3}$ Chodzi tu zwłaszcza o relatywizm epistemologiczny i etyczny.
} 
czegoś niepodważalnego, stałego. Mniej bądź bardziej świadomie otwieramy się więc na wynikającą z naszego doświadczenia wiedzę potoczną, zdroworozsądkową. Prawdopodobnie nie jest to reakcja charakterystyczna wyłącznie dla „trudnych czasów” (po)ponowoczesności, a raczej wpisane w ludzką naturę działanie.

O czerpaniu z tych pokładów, także przez reprezentantów nauki, i to bez względu na stan ich emocjonalno-intelektualnej równowagi (pewno jakoś zależnej od obowiązującego paradygmatu metodologicznego) czy chęć wyjścia z egzystencjalnego stresu, mogą świadczyć „wyznania” niektórych antropologów:

Jestem Słowianinem, urodzonym i wychowanym w najbardziej archaicznych i pierwotnych rejonach Europy. Mam więc wrodzoną znajomość moich stron rodzinnych. Mam, co więcej, osobiste doświadczenie obcowania z moimi chłopskimi ziomkami - doświadczenie, które zdobyłem nie tylko dzięki etnologicznym badaniom terenowym w Polsce, na Białorusi, Ukrainie i w krajach bałkańskich, lecz przede wszystkim dzięki bliskim przyjaźniom z wieloma mieszkańcami tych krajów.

O ile pamiętam, to nawet byłem piastowany przez wieśniaczkę z Białorusi, kraju słynącego w literaturze etnograficznej ze swoich przesądów, pierwotnych wierzeń, starodawnych obrzędów... [Obrębski 2005].

Do swych pozaakademickich doświadczeń i refleksji odwoływał się także Alfred Louis Kroeber:

[...] już wcześnie, prawie jako chłopiec, odczuwałem intuicyjnie, że wszelkie poszukiwanie początków jest próżne, i że proste, rzekomo specyficzne przyczyny zjawisk kulturowych i historycznych, czy to konkretne, czy ogólne [...], są fałszywe. Do dziś jestem pewien tych dwóch rzeczy [Kroeber 2007: 287].

Te dwie wypowiedzi działających w ubiegłym stuleciu badaczy oparte zostały o przemyślenia odnoszące się do wiedzy niepodręcznikowej, pochodzącej z subiektywnego doświadczenia, rzeczywistości doznanej przez nich osobiście [Kloch 2014: 8-9]. Ważne przy tym, że były one nie tylko wykorzystane w pracy obu uczonych, ale też rozwinięte i pozytywnie zweryfikowane. Zakładam, że wielu z nas, zagłębiając się w swój przedakademicki żywot, mogłoby podobne przykłady znaleźć. Zanim przejdę do 
rozwinięcia tych kwestii uruchamiając własną pamięć, chcę wskazać na jeszcze jeden istotny problem.

Chodzi o zjawisko przepływu idei, które jako apokryfy — ludowe mądrości, estetyczne wzorce, moralne zasady - w pewnym momencie wchodzą do kanonu kultury [Eichstead, Piątkowski 2003]. Badacze sięgający do historii antycznej Grecji twierdzą, że wiele z tego, o czym powiedzieli filozofowie Hellady, a co powtórzyli ich nowożytni następcy (również antropologowie) ${ }^{4}$, wcześniej wybrzmiało w strofach poetów, obficie czerpiących z pieśni ludu. Tak jest choćby z poezją Mimnermosa z Kolofonu, w twórczości którego odnajdujemy wywodzącą się z kultury biesiadnej wykładnię hedonizmu, dwa wieki później (IV w. p.n.e.) sformułowaną w filozofii Arystypa z Cyreny [Kumaniecki 1988: 95]. Bliższym przykładem sięgania do „korzennej” wiedzy mogą być zalecenia Adama Gostomskiego, autora pierwszego w Polsce podręcznika agrarnego. Mówi on, że w sprawie uprawy roli warto też „radzić się kmiotków” [Gostomski 1951] ${ }^{5}$. Podobnych przykładów uprawomocnienia gminnych treści wśród „encyklopedystów” jest naprawdę bez liku6.

Stąd różnego rodzaju ludowe wizje świata odzwierciedlone choćby w przysłowiach, traktowane są jako przejaw „zdrowego rozsądku”, swoistej „nauki” czy opinii ludu na temat „tego co jest”, „co widać”. Inna sprawa, że jest to wizja eklektyczna, sprzeczna, zabarwiona przesądami lub niezgodna z logiką (Hołówka 1986: 133-135). Pamiętajmy też o dwóch kierunkach przepływu idei (wiedzy), które z „pańskiego stołu” trafiają „pod strzechę”, by niekiedy powrócić do „salonu” w formie przeinaczonej, wyrażonej we właściwej sobie „gramatyce kulturowej”7. Dlatego wiele z nich należy traktować jako efekt swoistej percepcji ludu, dopasowania obcych wzorów do własnych możliwości i potrzeb, ale też jako wynik niezrozumienia ich „oryginalnego” (elitarnego) sensu8 .

\footnotetext{
${ }^{4}$ O filozofii, jako podglebiu antropologii, mówi m.in. Katarzyna Kaniowska [Kaniowska 1995: 62].

${ }^{5}$ Pierwsze wydanie $1588 \mathrm{r}$.

${ }^{6}$ Najwięcej jednak można ich znaleźć w różnych dziedzinach sztuki (malarstwo, muzyka, literatura).

${ }^{7}$ Termin „gramatyka kulturowa” to metawzór kultury (metaporządek) konstruujący przekonania jej uczestników i możliwości poznawania świata, którego obraz tworzą według matryc-wzorów [Pałubicka 2013: 14, 20].

${ }^{8}$ Mechanizm recepcji i przetwarzania treści elitarnych przez grupy „kulturowo upośledzone” to zjawisko uniwersalne. Jego przykładem jest choćby modyfikacja obecnych w kulturze popularnej motywów „kultury wysokiej”, jakiej dokonują „masy konsumenckie” [Barański 2010: 143-148].
} 
Podsumowując dotychczasowe wywody, można powiedzieć, że wiedza potoczna, jako konstrukt myślenia spontaniczno-praktycznego ${ }^{9}$, to pewien bagaż operacyjnych możliwości nabywanych drogą enkulturacji i bezpośrednich doświadczeń. Umiejętności te, zwłaszcza na podstawowym poziomie „radzenia sobie ze światem”, wykorzystywane są niemal bezrefleksyjnie i nawykowo. Wiedza potoczna kształtuje również pospolite wyobrażenia i sądy, ale jest niezależna od wiedzy naukowej, która wymaga uruchomienia myślenia metafizyczno-teoretycznego, opierającego się na bardziej abstrakcyjnych operacjach [Pałubicka 2006: 14, 45-46; Piasek 2011: 59-61]. Biorąc to pod uwagę wiedzę potoczną można ulokować nie tylko w historycznym konstrukcie pradziejów czy tradycyjnej kultury ludowej, ale też w szeroko pojętej kulturze życia codziennego o cechach kultury ludowej. Mam tu na myśli, najogólniej rzecz ujmując, przestrzeń współczesnej kultury popularnej/masowej, w której naukowe racjonalizmy i akademickie teorie są zdegradowane, zawieszone, mniej istotne lub nieobecne. Chodzi mi także o sytuacyjny i kontekstowy areał naszej codzienności, kiedy sięgamy do swych kulturowych „pierwocin”, gdy działamy spontanicznie, ale zazwyczaj sprawnie i skutecznie. Są to owe „immanentne pokłady osobowościowe”, które tkwią głęboko w tradycji i składają się na to, co za Józefem Bursztą można by nazwać „ludowym kształtem człowieka” [Burszta 1985: 331-332]. Odnosząc się do roli tego czynnika w pracy etnologa, uwagę swą kieruję na „praktykę ludową”, rozumianą jako równoległe do procedur akademickich działania zgodne z tzw. zdrowym rozsądkiem „zwykłego człowieka”. Czy jest to wskazanie na rozbrat z klasyczną nauką, jaki etnologia już uczyniła, choćby za sprawą rozkwitającego wciąż nurtu antropologii osobistej, odrzucającej rozróżnienie między praktykami subiektywnymi a obiektywnymi [Pomieciński 2009: 93-95]? Spoglądając w tę stronę, pozwolę sobie na przywołanie kilku, zanotowanych w mej pamięci faktów i zdarzeń.

W nawiązaniu do transferu myśli na osi kanon - apokryf pragnę przywołać, do dziś brzmiącą mi w uszach formułę, jaką zapamiętałem z dzieciństwa: „ja tam nic nie wiem, idę do kościoła”. Wypowiadała ją jedna z moich bogobojnych krewnych, która zawartą w tym oświadczeniu myśl wcielała w życie nie tylko w niedzielę, ale zawsze, gdy tylko spotykała

\footnotetext{
${ }^{9}$ Można rzec, że spontanicznego bardziej niż mniej, zgodnie z wykładnią myślenia potocznego A. Pałubickiej [2006: 12], i mniej niż bardziej, idąc za definicją wiedzy potocznej Geertza [2005: 81-85].
} 
się z przerastającymi ją problemami. Zacytowaną „mądrość”, często powtarzaną i ironicznie komentowaną przez niektórych członków mojej mieszczańskiej rodziny, postrzegam po latach jako dowód na głębokie osadzenie w kulturze codzienności, transcendentnego przeświadczenia o niedoskonałościach ludzkiej wiedzy, zagubieniu i nieporadności człowieka, a także o jego potrzebie odwołania się do absolutu. Przesłanie to wywołuje skojarzenie z sokratejskim „wiem, że nic nie wiem” i może być przykładem ludowej wersji namysłu filozofa, zdającego sobie sprawę z ograniczonych możliwości ludzkiego poznania, a zarazem poszukującego prawdy i cnoty [Wesoły 2006: 13-14]. Może być też echem kazania proboszcza, który zgodnie z nauką kościoła mówi wiernym, by w trudnych chwilach szukali pociechy w wierze. Bez względu na źródło „babcinej” sentencji, zestawienie jej z wysokiego lotu prawdami kanonicznymi jest dowodem na ich obecność i przyswajalność przez „szarego człowieka”, a jednocześnie potwierdza tendencję do zamykania ich w uproszczonej formule.

Kto wie zatem, czy jakiemuś zapatrzonemu w niebo pasterzowi, nie mogły wymknąć się słowa, choćby trochę przypominające słynne zdanie Immanuela Kanta: „niebo gwiaździste nade mną i prawo moralne we mnie”? Niezapisane słowa „chłopskiego filozofa”, za którymi stały refleksje jego „praktycznego rozumu”10, lub wysnute z ezoterycznej wiedzy zaklęcie szamana odnoszące się do innej perspektywy doświadczeń i wyobrażeń oraz intelektualno-symbolicznego (mitycznego) potencjału „człowieka pierwotnego"11?

Przykładem funkcjonowania wśród „prostego ludu” tematów, o które na ogół go nie podejrzewamy, jest rozmowa dwóch pracujących w lesie mężczyzn, jakiej przysłuchiwałem się podczas wakacji spędzonych w połowie lat 70. ubiegłego wieku na Kielecczyźnie. Zapamiętałem ją m.in. dlatego, że jej treść przypominała rozważania etnologów, a dotyczyła tożsamości lokalnej mieszkańców regionu, gdzie mieszkała moja rodzina. Pierwszy z rozmówców — wozak z oddalonej o kilkanaście kilometrów wsi — tłumaczył miejscowemu robotnikowi leśnemu, jakie są między nimi różnice. Właściciel dorodnego konia pociągowego i wozu, określający się mianem polak, swego skromnego kolegę nazywał lesiakiem. Wywód ten,

\footnotetext{
${ }^{10}$ Nawiązuję tu do dzieła I. Kanta: Krytyka praktycznego rozumu (Kritik der praktischen Vernunft, Riga 1788) i jego teorii imperatywu etycznego, odwołującej się do potencji „rozumu praktycznego".

${ }^{11}$ O praktycznej, „domowej filozofii”, rdzennych mieszkańców Afryki, wspomina Franz Boas [Boas 2010: 222].
} 
artykułowany prostym językiem „ludzi pracy”, bazował na znajomości geografii małej ojczyzny, charakteryzującej się różnicami w krajobrazie. Polaki, jak twierdził wozak, to „prawdziwi gospodarze” z bezleśnej okolicy gdzie przeważały wsie rolnicze z gospodarstwami o dużej powierzchni. Nazwa lesiaki obejmowała wsie puszczańskie, położone na glebach słabych z gospodarstwami małymi i rozdrobnionymi. Polak wyraźnie dominował w tej rozmowie zwracając się do lesiaka adekwatnie do zaprezentowanej dychotomii, czyli jak gospodarz do parobka („no wiesz, Józio...”), co ten przyjmował z pokorą. Po załadunku drzewa na wóz przyszedł czas na chłopskie „śniadanie na trawie”. Pojawiła się wódka i niewyszukana zakąska, czyli ryba z puszki w sosie pomidorowym. Z zainteresowaniem obserwowałem, jak ucztujący poradzili sobie z brakiem widelców. Wystarczyło okorować końce kijków wyciętych z pędów młodego drzewa i lekko zaostrzyć je scyzorykiem. Jakież to proste i genialne, i jak zręcznie wykonane - pomyślałem. Postanowiłem przerwać mą milczącą asystę i napomknąłem coś o „rabunkowej trzebieży lasów”. Odpowiedzią był gromki śmiech, a potem padło znane porzekadło: „nie było nas, był las...”. Ten „ekologiczny” wątek spuentował polak: „a z czego wyżyłyby lesiaki, jakby nie zarobiły w lesie?”. Tak mniej więcej brzmiało jego retoryczne pytanie zadane z udawaną troską o swego „towarzysza pracy”.

Zupełnie inny stosunek do lasu reprezentował Stachu ze wsi K., w której wielokrotnie spędzałem wakacje. Zapamiętałem go dobrze, bo miał on tu opinię dziwaka: małomównego, powolnego „starego kawalera” i — co chyba wiele tłumaczy — stroniącego od alkoholu „odludka”. Spotykałem go dość często, bo kolegowałem się trochę z jego siostrzeńcem, ale nigdy dłużej nie rozmawialiśmy. Dystans wieku (ponad trzydzieści lat, jakie liczyła wtedy Polska Ludowa) i milczące usposobienie pana Stanisława robiły swoje. Jedną $\mathrm{z}$ wielu anegdot powtarzanych na jego temat była Wyprawa Stacha do lasu po drzewo. Jej bohater przed wprowadzeniem w ruch siekiery miał długo chodzić z zadartą do góry głową i „modlić się” do drzew. Bywało, że wybór odpowiedniego chojaka trwał kilka dni i Stachu wielokrotnie wracał do domu pustym wozem. Poprosiłem kiedyś swojego stryja, żeby mi wytłumaczył, o co tu chodzi. Usłyszałem, że Stachu jest z lasem „za pan brat”, zna się na drzewach jak mało kto i zanim postawi krzyżyk na pniu starannie je ogląda, bez względu na to czy szuka paliwa na opał, czy materiału na deski. Do pieca powinno trafić drzewo słabe, chore i krzywe, a nie zdrowe i proste. 
Krótko mówiąc Stachowi chodzi o to by „nie marnować lasu”. Miejscowi chłopi nie rozumieli takiego „cackania się”, oni „rżnęli jak leci”.

Z braku miejsca nie wyliczę innych mądrości Stacha, ale gdybym miał wskazać „chłopskiego filozofa”, który dojrzał rozpostarte nad sobą „niebo gwiaździste...”, to byłby to właśnie on.

W przedstawionych tu scenach z lat minionych dostrzegam oczywiście także siebie - toruńskiego licealistę na wiejskich wakacjach, który nieświadom jeszcze swych etnograficznych pasji, naturalnie i bezwiednie prowadzi „obserwacje uczestniczące”, doświadcza „obcości”, uczy się rozmawiać i słuchać, sporządza notatki w pamięci zainstalowanego w głowie „komputera” (headnotes) ${ }^{12}$. Te interakcje, nawiązując do zacytowanego wyżej „wyznania” Józefa Obrębskiego, zaszczepiły we mnie „wrodzoną znajomość stron rodzinnych”, umiejętność „obcowania z moimi chłopskimi ziomkami — doświadczenie, które zdobyłem [...], przede wszystkim dzięki bliskim przyjaźniom z wieloma mieszkańcami [...]” [Obrębski 2005]. Pomińmy w tej chwili problem zwodniczości i wybiórczości tego rodzaju „odgrzewanej” pamięci, a poprzestańmy na jej roli poznawczej [Kaniowska 2003; 69, 83].

Zdaję sobie sprawę, że podobną praktykę do mojej amatorskiej „etnografii” ma za sobą wielu etnologów i niedoszłych do zawodu wędrowców. Wiem też, że obserwacje typu etnograficznego nie są wyłączną domeną światłych przedstawicieli nauk o człowieku. Opisy „obcych”, śledzenie ich zachowań, wytykanie wad i opatrywanie nazwami (przezwiskami) wskazującymi osobliwe cechy „innych”, to przecież naturalne zachowania ludów, to ich „tubylcza etnografia”. Antropologia badając zjawiska etnocentryzmu, megalomanii grupowych czy plemiennych ksenofobii, potwierdza to od dawna [Burszta 1998: 15-18]. Mamy zatem do czynienia z etnografią ludową, tak samo jak z literaturą, sztuką, mądrością, wiedzą (filozofią), religią, lecznictwem i prawem (zwyczajowym)? Wydaje się, że jest to tylko kolejne, retoryczne pytanie. Sama antropologia zakwestionowała wszak wielokrotnie nadrzędność własnego spojrzenia, podważyła własną epistemologię [Sikora 2009: 62].

Powracając do doświadczeń z zakresu wiedzy potocznej, a ściśle do jej sfery praktyczno-poręcznościowej, wejdźmy w końcu na bliskie mi podwórko muzealnej etnografii. Potencjał tej domeny poznawczej wydaje się w pracy z rzeczami (muzealiami) wykorzystywany dość często i nie

${ }^{12} \mathrm{O}$ takich antropologicznych „przypisach w głowie” wspomina m.in. Kristen Hastrup [Hastrup 2008: 69]. 
raz ze sporym pożytkiem. Mam tu na myśli szeroki zakres spraw organizacyjno-technicznych i porządkowych w obrębie różnych przestrzeni, także magazynowych i wystawienniczych (również na wolnym powietrzu). Wiedza potoczna w muzealnej codzienności jest przydatna, zwłaszcza tam gdzie liczy się mniej bądź bardziej doraźny efekt. Chodzi oczywiście o podstawowy, „poręcznościowy” aspekt działania, a nie o bardziej abstrakcyjne koncepcje merytoryczne, w których sięgamy do wiedzy fachowej. Muzeum to przecież także placówka naukowa i biorąc pod uwagę jego dyscyplinarną specjalizację, w tym wypadku etnografię (etnologię/antropologię kulturową), powinno uwzględniać obowiązujące paradygmaty i wdrażać programy, jakie powstają na gruncie akademii [Barański 2010: 357; Święch 2014: 148]. Dotyczy to również usługowych sektorów muzeum, które reprezentują inne dyscypliny wiedzy, szczególnie archiwistykę, bibliotekoznawstwo i konserwację, ale też edukację, promocję czy fotografię ${ }^{13}$.

Wykorzystanie wiedzy potocznej możemy jednakowoż odnotować w niektórych przedsięwzięciach o charakterze naukowym, choć w ograniczonym zakresie, i to głównie na etapie przygotowawczym. Mam tu na myśli logistykę badań terenowych, obozów naukowych, organizację wystaw, konferencji, zjazdów czy „imprez” kulturalno-oświatowych (prelekcji, spotkań, kiermaszów, wernisaży). Bardzo często funkcjonujemy tu bez podręczników i instrukcji kierując się praktyką zawodową, ale też „zdrowym rozsądkiem” i doświadczeniem życiowym. Można powiedzieć, że nasze operacyjne kompetencje są w wielu przypadkach zdeterminowane podwójnie, co przypomina trochę dychotomię natura (doświadczenie życiowe/wiedza potoczna) — kultura (doświadczenie zawodowe/wiedza naukowa).

Dobrym przykładem przenikania się tych dwóch sfer w działaniu jest organizacja ekspozycji muzealnych. Autor scenariusza przekładając swój pomysł na powierzchnię sali wystawowej i materię przedmiotów (eksponaty, stelaż), współpracuje tu z plastykiem (koncepcja plastyczna) i wykonawcą (realizacja techniczna). Teoretyczne założenia scenariusza, będącego wynikiem akademickiego potencjału kustosza oraz projekt licencjonowanego artysty, spotykają się z warsztatem wykwalifikowanego „rzemieślnika”. Wszyscy są profesjonalistami w danej dziedzinie i działają — przynajmniej w założeniu - według kanonów wiedzy, sztuki i rzemiosła. W ten rozpisany plan „dzieła artystycznego” jakim wystawa przecież jest [Święch 1999:

\footnotetext{
${ }^{13}$ Oraz inne działy obecne w strukturze wielu instytucji kultury (księgowość, kadry, pracownie techniczne, itp.).
} 
12], wkrada się niekiedy przypadek (chaos) ${ }^{14}$. Przestrzeń pomiędzy myśleniem naukowym, wrażliwością estetyczną i technicznym pragmatyzmem, musi wypełnić „twórcza inwencja” i „działanie praktyczne”. Otwiera się wówczas bagaż wiedzy potocznej, do którego zaglądamy „[...] gdy trzeba to robić, a odwołanie do nauki jest zbyt trudne” [Czerwiński 1986: 6] lub gdy nie ma na to czasu.

Na podstawie doświadczenia mogę powiedzieć, że bardzo dobrze w takich sytuacjach sprawdzają się nasi koledzy z „ekipy wykonawczej”. Ich wiedza, wyniesiona przecież także spoza wyuczonego rzemiosła, niekiedy ratowała nas z opresji. Chodzi o kwestie związane z instalacją trudnych ekspozycyjnie obiektów, poszukiwaniem dla nich lepszego miejsca czy z montażem nietypowego stelażu. Niepodręcznikowa wynalazczość wiele razy pozwoliła skorygować teoretyczne założenia, fabryczne mankamenty, niedoskonałość materiału, ale też nasze przeoczenia czy błędy. Jeszcze więcej miejsca dla sprawdzenia walorów tego rodzaju wiedzy są ekspozycje na wolnym powietrzu. Powyższe uwagi można też odnieść do zagospodarowywania powierzchni historycznych budynków (kamienice, arsenały, spichlerze) adaptowanych na potrzeby muzealnictwa, a zwłaszcza na urządzenie w tych osobliwych wnętrzach, magazynów zbiorów.

Niejednokrotnie też pracownik z dyplomem w kieszeni przekonuje się, że jego wiedza teoretyczna, choćby na temat rzemiosła ludowego, blednie w obliczu praktycznych umiejętności zaproszonego na muzealne warsztaty garncarza czy plecionkarza. Przykładów tego rodzaju pouczających konfrontacji etnografowie z pewnością mogliby podać wiele. Z moich obserwacji wynika również, że muzealnicy pochodzący ze środowiska wiejskiego na ogół lepiej radzą sobie ze zrozumieniem działania narzędzi stosowanych w gospodarstwie oraz z opisem takich muzealiów. Inna sprawa, że chyba zawsze stanowili oni znakomitą mniejszość merytorycznej kadry.

Wiedza „oddolna” wraz z tą „wysoką” przenikają się więc nieustannie, nie tylko zresztą w muzealnej czy akademickiej rzeczywistości. Wyznaczenie zakresów tych dwóch sił oraz wspólnych pól ich oddziaływania wydaje się jednak trudne. Poprzestańmy więc na tym, że „ludowa mądrość” czy „chłopska roztropność”, jako afirmacje myślenia spontaniczno-praktycznego i formuły intelektualnej dyspozycji, są obecne w naszym życiu, kierując postępowaniem człowieka w różnych sytuacjach. Radzenie sobie ze światem

${ }^{14} \mathrm{O}$ roli przypadku w procesie tworzenia dzieł artystycznych obszernie pisze Rafał Koschany [Koschany 2016]. 
według reguł myślenia potocznego nie ogranicza się jednak do sprawności w opanowaniu świata rzeczy, a dotyczy także sposobów radzenia sobie w życiu. Ta pragmatyka ma swoją aplikacyjno-praktyczną odmianę polegającą m.in. na umiejętności korzystania z informacji i wiedzy naukowej, na uważnym patrzeniu, trafnych wyborach i logicznym łączeniu faktów ${ }^{15}$. Objawia się w przyjmowanych przez nas strategiach działania, ułatwiających osiągnąć wyznaczone cele, choćby na niwie kariery zawodowej (realizacja wystawy, wydanie publikacji, uzyskanie stopnia naukowego, awans). Często wiąże się to z indywidualnymi talentami z zakresu kontaktów interpersonalnych, które pozwalają stworzyć dobrą atmosferę wokół planowanego projektu, znaleźć grono sprzymierzeńców czy zdystansować konkurencję. Są to umiejętności nabyte z doświadczenia i obserwacji, czasem także ze studiowania fachowej lektury. Kompetencje wykorzystywane powszechnie, w każdym środowisku społeczno-zawodowym.

Zainteresowanie antropologii problematyką wiedzy potocznej, przy uznaniu walorów tej dyspozycji — „wcale nie gorszej od wiedzy naukowej”, którą Geertz nazywa „użyteczną fikcją” [Czaja 2005: 172; Barański 2010: 91] — może rodzić pytania o kondycję samej antropologii. Mam tu na myśli, wyrażaną przez wielu jej przedstawicieli, nieufność wobec własnej profesji, autoironię lub „autokrytyczną pasję” sprowadzającą się choćby do pytania czy antropologia jest nauką czy sztuką [Kaniowska 1999: 125]. Kwestionująca niekiedy samą siebie i przekraczająca granice innych dyscyplin, antropologia postmodernistyczna - refleksyjna, relatywizująca, pluralistyczna, dialogizująca — częściej zadaje trudne pytania niż udziela odpowiedzi [Kuligowski 2001: 14, 81]. Konsekwencją takiej postawy jest możliwość stawiania wniosków przeciwstawnych, lecz równoprawnych, bo prawda stała się ideałem, a nie osiągalnym celem poznawczym [Kuligowski 2001: 66, 72; Kaniowska 1995: 63] ${ }^{16}$. I nie o kwestię słuszności czy bezzasadności przekonań naukowych chodzi, a o to, że sama ich wiarygodność jest problematyczna [Kuligowski 2001: 118-119]. Ten stan intelektualnego, twórczego napięcia, otwierający nas na kulturowe wielogłosy, reinterpretacje i dekonstrukcje, nawet u sympatyzującego relatywisty budzi niekiedy

\footnotetext{
${ }^{15}$ Jest to praktyczna aplikacja efektów myślenia teoretyczno-metafizycznego [Pałubicka 2006:51], którą można zaliczyć do kategorii tzw. „inteligencji wrodzonej”.

${ }^{16} \mathrm{~W}$ ten sposób antropologia nawiązuje do sokratejskiej wykładni: nauka (filozofia) to sztuka zadawania pytań i kwestionowania odpowiedzi. Antropolog, tak jak filozof, zdaje sobie sprawę, że nie jest mędrcem (sophos) dlatego że wie, ale że dąży do wiedzy (jest philo-sophos) [Wesoły 2006: 23, 26].
} 
tęsknotę za „utraconym rajem” obiektywizmu i pozytywistycznego „ładu”. Zdając sobie sprawę, że nie ma powrotu z drogi po ruchomych piaskach postmodernizmu, na co dzień próbujemy jednak znaleźć twardy grunt pod nogami: zatapiamy się w potoczności.

Dla zrozumienia, jak w danym systemie społeczno-kulturowym współistnieć mogą dwie, tak różne normy wiedzy — potocznej i naukowej — niech posłuży przykład szachownicy, który zapożyczam tu od Wojciecha Burszty [2008: 164-165]. Na tej samej planszy, a nawet tymi samymi pionkami, raz możemy grać w szachy, a innym razem w warcaby. Chodzi o to, że kiedy gramy „W damkę” musimy zawiesić swe wyrafinowane kompetencje szachisty. Znając przebiegłe ruchy kilku szlachetnych figur, w warcabach zwykłego pionka przesuwamy tylko o jedno pole, wprawdzie po przekątnej, ale za to do przodu.

\section{Bibliografia}

\section{Barański Janusz}

2010: Etnologia i okolice. Eseje antyperyferyjne, Kraków: Wydawnictwo Uniwersytetu Jagiellońskiego.

\section{Boas Franz}

2010 Umyst człowieka pierwotnego, przeł. M. Pawluczuk, Kraków: Zakład Wydawniczy NOMOS.

\section{Brocki Marcin}

2012: Sposoby artykulacji potocznych doświadczeń a porządek doświadczenia wymuszony praktyka etnograficzna, [w:] Humanistyka i dominacja. Oddolne doświadczenia społeczne w perspektywie zewnętrznych rozpoznań, red. T. Rakowski, A. Malewska-Szałygin, Warszawa: Instytut Etnologii i Antropologii Kulturowej Uniwersytetu Warszawskiego.

\section{Bronk Andrzej}

1996: Krajobraz postmodernistyczny, „Ethos”, nr 33-34.

\section{Burszta Józef}

1985: Chłopskie źródła kultury, Warszawa: Ludowa Spółdzielnia Wydawnicza.

\section{Burszta Wojciech, J.}

1998: Antropologia kultury. Tematy, teorie, interpretacje, Poznań: Zysk i s-ka Wydawnictwo s.c.

2008: Świat jako więzienie kultury. Pomyślenia, Warszawa: Państwowy Instytut Wydawniczy.

\section{Brzeziński Dariusz}

2013: Teoria socjologiczna jako narzędzie zmiany? Analiza performatywnego wymiaru myśli społecznej Zygmunta Baumana, „Kultura i Społeczeństwo”, nr 2. 


\section{Buchowski Michał}

1995: Fratrie i klany nowo-plemienia antropologów w Polsce, [w:] Etnologia polska między ludoznawstwem a antropologia, red. A. Posern-Zieliński, Poznań: Prace Komitetu Nauk Etnologicznych PAN, nr 6.

\section{Czaja Dariusz}

2005: Anatomia duszy. Figury wyobraźni i gry językowej, Kraków: Wydawnictwo Uniwersytetu Jagiellońskiego.

\section{Czerwiński Marcin}

1986: Przedmowa, [w:] T. Hołówka, Myślenie potoczne. Heterogeniczność zdrowego rozsądku, Warszawa: Państwowy Instytut Wydawniczy, Biblioteka Myśli Współczesnej.

\section{Domańska Ewa}

1996: Historiografia czasu postmodernizmu po postmodernizmie (retrospekcja), [w:] Wobec kultury. Problemy antropologa, red. G. E. Karpińska, „Łódzkie Studia Etnograficzne”, t. 35.

\section{Eichstaedt Jarosław, Piątkowski Krzysztof (red.)}

2003: Nie-złota legenda: kanoniczność i apokryficzność w kulturze, Ożarów: Colloquia Ethnologica 1, Towarzystwo Przyjaciół Muzeum Wnętrz Dworskich.

\section{Geertz Clifford}

2005: Wiedza lokalna. Dalsze eseje z zakresu antropologii interpretatywnej, przeł. D. Wolska, Kraków: Wydawnictwo Uniwersytetu Jagiellońskiego.

\section{Gellner Ernest}

1997: Postmodernizm, rozum i religia, przeł. M. Kowalczuk, Warszawa: Państwowy Instytut Wydawniczy.

\section{Gostomski Anzelm}

1951: Gospodarstwo, Wrocław: Wydawnictwo Zakładu Narodowego im. Ossolińskich, Seria: Biblioteka Narodowa, Seria I, Nr 139.

\section{Hastrup Kirsten}

2008: Droga do antropologii. Między doświadczeniem a teoria, przeł. E. Klekot, Kraków: Wydawnictwo Uniwersytetu Jagiellońskiego.

\section{Hołówka Teresa}

1986: Myślenie potoczne. Heterogeniczność zdrowego rozsądku, Warszawa: Państwowy Instytut Wydawniczy, Biblioteka Myśli Współczesnej.

\section{Jastrzębski Bartosz}

2017: Vestigia Dei, Warszawa: Fundacja Augusta Hrabiego Cieszkowskiego.

\section{Kacperczyk Anna}

2014: Autoetnografia - technika, metoda, nowy paradygmat? O metodologicznym statusie autoetnografii, „Przegląd Socjologii Jakościowej”, tom 10, nr 3, www. przegladsocjologiijakosciowej.org., data odczytu: 20.04.2020.

\section{Kaniowska Katarzyna}

1995: Inspiracje i konsekwencje antropologizacji etnologii polskiej, [w:] Etnologia polska między ludoznawstwem a antropologią, red. A. Posern-Zieliński, Poznań: Prace Komitetu Nauk Etnologicznych Polskiej Akademii Nauk, nr 6.

1999: Opis — klucz do rozumienia kultury, „Łódzkie Studia Etnograficzne”, t. 39. 
2003: Antropologia i problem pamięci, „Konteksty. Polska Sztuka Ludowa”, nr 3-4.

\section{Kloch Zbigniew}

2014: Kultura doświadczenia potocznego. Semiotyczne aspekty codzienności Eseje, Warszawa, Wydawnictwa Uniwersytetu Warszawskiego.

\section{Koschany Rafał}

2016: Przypadek. Kategoria egzystencjalna i artystyczna $w$ literaturze i filmie, Toruń: Wydawnictwo Naukowe Uniwersytetu Mikołaja Kopernika.

\section{Krajewski Marek}

2005: Kultury kultury popularnej, Poznań: Wydawnictwo Naukowe Uniwersytetu im. Adama Mickiewicza, Seria Socjologia, nr 34.

\section{Kroeber Alfred Louis}

2007: Istota kultury, [w:] Świat człowieka — świat kultury. Antologia tekstów klasycznej antropologii, red. E. Nowicka, M. Głowacka-Grajper, przeł. P. Sztompka, Warszawa: Wydawnictwo Naukowe PWN.

\section{Kubina Wiktor}

1998: Ogólna charakterystyka postmodernizmu (aspekt filozoficzny), „Sympozjum”, r. 2, 2(3).

\section{Kuligowski Waldemar}

2001: Antropologia refleksyjna. O rzeczywistości tekstu, Poznańskie Studia Etnologiczne nr 2, Poznań: Wydawnictwo Poznańskie.

\section{Kumaniecki Kazimierz}

1988: Historia kultury starożytnej Grecji i Rzymu, Warszawa: Państwowe Wydawnictwo Naukowe.

\section{Obrębski Józef}

2005: Dzisiejsi ludzie Polesia i inne eseje, opr. A. Engelking, Warszawa: Oficyna Wydawnicza Rytm, Wydawnictwo Instytutu Filozofii i Socjologii Polskiej Akademii Nauk.

\section{Pałubicka Anna}

2006: Myślenie w perspektywie poręczności a pojęciowa konstrukcja świata, Bydgoszcz: Oficyna Wydawnicza Epigram.

2013: Gramatyka kultury europejskiej, Warszawa: Oficyna Wydawnicza Epigram.

\section{Piasek Wojciech}

2011: Historia jako wiedza lokalna. „Antropologiczne przesunięcie” $w$ badaniach nad historiografia PRL, Toruń: Wydawnictwo Naukowe Uniwersytetu Mikołaja Kopernika.

2017: Etnografia myśli potocznej w dziedzinie pozaakademickich relacji z przeszłością. Myśl potoczna jako przedmiot badań historii historiografii, HISTORIA@TEORIA, nr 2017/2(4), http://dx.doi.org/10.14746/ht.2017.4.2.09, data odczytu: 04.05.2019.

\section{Pomieciński Adam}

2009: Pomiędzy antropologia zaangażowana a osobista, [w:] Zanikające granice. Antropologizacja nauki i jej dyskursów, red. A. Pomieciński, S. Sikora, Poznań: Biblioteka Telgte. 


\section{Posern-Zieliński Aleksander}

1995: Etnologia i antropologia kulturowa w formalnej i rzeczywistej strukturze nauki, [w:] Etnologia polska między ludoznawstwem a antropologia, red. A. Posern-Zieliński, Poznań: Prace Komitetu Nauk Etnologicznych Polskiej Akademii Nauk, nr 6.

\section{Robotycki Czesław}

1992: Etnografia wobec kultury współczesnej, Kraków: Wydawnictwo Uniwersytetu Jagiellońskiego.

1995: O banalizacji tekstów w etnografii, [w:] Etnologia polska między ludoznawstwem a antropologia, red. A. Posern-Zieliński, Poznań: Prace Komitetu Nauk Etnologicznych Polskiej Akademii Nauk, nr 6.

\section{Sikora Sławomir}

2009: Odwrócone spojrzenie albo antropologizacja antropologii, [w:] Zanikające granice. Antropologizacja nauki i jej dyskursów, red. A. Pomieciński, S. Sikora, Poznań: Biblioteka Telgte.

\section{Sulima Roch}

2000: Antropologia codzienności, Kraków: Wydawnictwo Uniwersytetu Jagiellońskiego.

\section{Święch Iwona}

1999: Czytanie wystawy. Naprawdę piękny jest tylko teatr nieruchomy, „, Rocznik Muzeum Etnograficznego w Toruniu”, tom 2.

\section{Święch Jan}

2014: Uwagi na marginesie ankiety: Polskie muzeum etnograficzne w XXI wieku w czasopiśmie „Zbiór Wiadomości do Antropologii Muzealnej”, „Zbiór Wiadomości do Antropologii Muzealnej”, nr 1/2014, http://zwam.ptl.info.pl/wp-content/uploads/ 2014/08/Swiech.pdf, data odczytu: 01.04.2020.

\section{Święch Jan, Tubaja Roman}

2001: Szkoły i kierunki w etnologii a muzealnictwo etnograficzne w Polsce, [w:] Przeszłość etnologii polskiej w jej teraźniejszości, red. Z. Jasiewicz, T. Karwicka, Poznań: Prace Komitetu Nauk Etnologicznych Polskiej Akademii Nauk, nr 10.

\section{Wesoły Marian}

2006: „Najwyższe dobro człowieka”-słowa Sokratesa w obliczu wyroku śmierci, [w:] Filozofia wobec nauki, człowieka i społeczeństwa, red. K. Łastowski, P. Zeidler, Poznań: Wydawnictwo Naukowe Instytutu Filozofii Uniwersytetu im. Adama Mickiewicza.

\section{Artur Trapszyc}

\section{Between Academia and Life: Scientific and Common Knowledge in the View of the Personal and Professional Experience of an Ethnographer}

Postmodern anthropology, revising the canons of positivist ethnography, has been for long drawing attention to the role of a researcher in the perception and description of the studied reality. In this essay I would like to focus on how the personal experience and non-academic knowledge of an ethnologist influence their professional activities, what influences their 
actions in the field, in the office, in the storeroom and during the arrangement of museum exhibitions. To what extent do they affect their academic knowledge, and how often do ethnologists reach for common knowledge?

Referring to my own memories and observations from before the academic years, I try to support the main thesis of my article that the boundary between the two categories of knowledge is blurred, and that the scope of subjects they penetrate overlap in many places. A contemporary man, including an educated ethnologist, is constantly confronting common thinking style with scientism, and in everyday life they often mix these two orders. This is also true of professional life, as I present in a few examples from the museum.

Some of the "scientific truths" and "folk wisdom", even though they are worded differently, they sometimes coincide. Cognitive and ethical relativism, which has become established in postmodern anthropology and penetrated global culture, in turn causes a significant gap between them. The postmodern shape of culture, tinged with idealistic liberalism, often results in cognitive disorientation. This intellectual discomfort and state of uncertainty cause many academics to yearn for the "old", positivist order. On the other hand, trying to find an orderly world, we open ourselves to our life experiences and the so-called common sense.

Keywords: scientific knowledge, common knowledge, personal experience, professional experience, autoethnography 
